\title{
Effects of climate change on silage maize production potential in the European Community
}

\author{
J. Wolf ${ }^{*, a}$, C.A. van Diepen ${ }^{\mathrm{b}}$ \\ ${ }^{a}$ Department of Theoretical Production Ecology, Wageningen Agricultural University, Bornsesteeg 65 , \\ P.O. Box 430,6700 AK Wageningen, Netherlands \\ ${ }^{\mathrm{b}} D L O$, The Winand Staring Centre, P.O. Box 125,6700 AC Wageningen, Netherlands
}

Received 16 August 1993; revision accepted 19 January 1994

\begin{abstract}
Silage maize production in the main arable areas of the European Community (EC) was calculated with a simulation model, WOFOST (World Food Studies model), using historical weather data and average soil characteristics. The sensitivity of the model to individual weather variables was determined. Subsequent analyses were made using climate change scenarios with and without the direct effects of increased atmospheric $\mathrm{CO}_{2}$. The impact of crop management (sowing date and cultivar type) in a changed climate was also assessed. A climate change scenario results generally in larger production for the northern EC and identical or smaller productions for the central and southern EC. The various climate change scenarios used appear to yield considerably different changes in production, both for each location and for the EC as a whole. Management analyses show that for both present and scenario climates the greatest production will be attained by varieties with a long growth duration, and that for climate change as in the scenarios the sowing date should be advanced.
\end{abstract}

\section{Introduction}

As agricultural production is greatly affected by climate, any changes in climate which may result from increasing concentrations of greenhouse gases in the atmosphere could have dramatic consequences for agricultural production potential. In this study the effects of climate change on the production of silage maize in the European Community (EC) and the implications for crop management were analysed.

The relationship between climate, crop growth and production is complicated, as a

* Corresponding author.

0168-1923/94/\$07.00 (C) 1994 - Elsevier Science B.V. All rights reserved SSDI 0168-1923(94)02144-9 
large number of climate, soil, landscape and crop characteristics are involved. In addition, crop growth appears to respond to changing conditions mainly in a nonlinear way (Nonhebel, 1993). For example, this may lead to a lower production for maize both in situations where the average temperature rises and where the average temperature remains identical but its variability increases (Semenov et al., 1993). As a consequence, the effects of climate change on crop production cannot be described in terms of simple and average relationships between the two. In the last two decades methods have been developed for estimating the production levels of crops grown under well-specified conditions. These methods are based on the application of crop growth simulation models, combining knowledge about crop characteristics and their interactions with the environment.

Before evaluation of the effects of climate change, the sensitivity of silage maize production to separately changed weather variables was determined. To analyse the effects of climate change on the production potential of silage maize in the EC, 20 locations representative of the main agro-climate conditions in the EC were chosen. The production was calculated for current and changed climate conditions at these locations, using climate change scenarios (Barrow, 1993). The direct effect of increasing atmospheric $\mathrm{CO}_{2}$ concentrations was incorporated in the production calculations for changed climate and the impact of changes in crop management was also determined.

\section{Methods}

\subsection{Model description}

A dynamic crop growth model WOFOST (World Food Studies model), developed for calculating agricultural production potential on the basis of physiological, physical and agronomic information, was used. This model can easily be applied to a large number of combinations of weather data, soil characteristics and crop species. The principles underlying this model have been discussed in detail by Van Keulen and Wolf (1986), and the implementation and structure have been described by Van Diepen et al. $(1988,1989)$. Its application for quantitative land evaluation and for regional analysis of the physical potential of crop production has been described by Van Keulen et al. (1987) and Van Diepen et al. (1990), and its use for analysis of the effects of climate change on crop production has been discussed by Van Diepen et al. (1987) and Wolf and Van Diepen (1991).

In the model the growth of a crop is simulated from start to maturity on the basis of physiological processes as determined by the crop's response to environmental conditions. The simulation is carried out in time steps of 1 day. The major processes considered are $\mathrm{CO}_{2}$ assimilation, respiration, partitioning of assimilates to various plant organs, transpiration and phenological development. To calculate daily $\mathrm{CO}_{2}$ assimilation, a photosynthesis-light response curve of individual leaves is used first to determine the instantaneous assimilation rate per leaf layer. By application of the Gaussian integration method (Goudriaan, 1986) assimilation rates over the canopy 
and over the day are calculated (Spitters, 1986). Part of the assimilates is used for respiration and hence does not contribute to crop growth. The respired fraction depends on the temperature and the chemical composition of plant tissue (Spitters et al., 1989). The rate of phenological development depends mainly on the temperature, and determines the partitioning of assimilates (Van Keulen and Wolf, 1986; Spitters et al., 1989). Potential rates of soil evaporation and crop transpiration are calculated with the Penman formula (Frère and Popov, 1979).

Two levels of crop production are calculated: (1) the potential production, which is determined by crop characteristics, temperature and solar radiation, and can be realized in situations where the supply of water and plant nutrients, and crop management are optimum; (2) the water-limited production, which is determined by crop characteristics, temperature, solar radiation and water availability (dictated by rainfall pattern and soil physical properties), and can be realized in situations where the supply of plant nutrients and crop management are optimum.

Available soil moisture in the root zone follows from quantification of the water balance, including rainfall, surface runoff, soil surface evaporation, crop transpiration and leaching from the root zone. If the moisture content in the root zone is too low or too high, water uptake by the plant roots is reduced, stomata close and the water-limited growth is reduced -in a dry soil owing to water shortage, in a wet soil owing to oxygen shortage.

Grain production of maize is particularly sensitive to drought during flower initiation, tasselling and silking. If severe drought occurs during these phenological stages, the number of grains and hence the maximum of grain production are greatly reduced (Denmead and Shaw, 1960; Claassen and Shaw, 1970a,b; Shaw, 1977; Bloc et al., 1978). In such situations with strong drought reduction of the grain production, the total dry matter production of maize and its animal nutrition value appear nevertheless to remain almost the same (Te Velde, 1986). As only the effects of climate change on total dry matter production were studied, such a relationship between the maximum of grain production and the degree of drought stress during the sensitive stages was not included in the model version used here.

In the model the direct effect of increasing atmospheric $\mathrm{CO}_{2}$ on the growth and transpiration of the crop is taken into account. For $\mathrm{C} 4$ plants such as maize, and other tall tropical grasses such as millet, sorghum and sugarcane, the photosynthetic response to $\mathrm{CO}_{2}$ is very steep until an atmospheric $\mathrm{CO}_{2}$ concentration clearly below the present one. Hence, the rate of $\mathrm{CO}_{2}$ assimilation does not change at increasing atmospheric $\mathrm{CO}_{2}$, even under high light intensities (Goudriaan and Unsworth, 1990). Many literature reviews (Kimball, 1986; Cure and Acock, 1986) however, indicate increases in maize yield of $10-15 \%$ at doubled atmospheric $\mathrm{CO}_{2}$. Probably such yield increases were mainly caused by an increase in water use efficiency, so that in the model calculations the rate of $\mathrm{CO}_{2}$ assimilation is kept constant at increasing $\mathrm{CO}_{2}$. Concurrently, the transpiration rate of the maize crop greatly decreases. For example, doubling of the actual atmospheric $\mathrm{CO}_{2}$ concentration reduces the transpiration rate of a maize crop by $26 \%$ of the original value (Goudriaan and Unsworth, 1990), as based on calculations with a stratified micrometeorological model (Goudriaan, 1977; Chen, 1984) and also indicated by literature 
reviews by Cure (1985) and Cure and Acock (1986). On the basis of this information, calculated transpiration rates are corrected for increasing $\mathrm{CO}_{2}$.

\subsection{Data}

To apply the model, data that specify crop growth and phenological development are required, including information on initial crop weight, properties that determine assimilation and respiration processes and response to moisture stress, partitioning of assimilates to plant organs, life span of leaves, and death rates of plant organs. For the most part, a standard crop data set was used (Van Heemst, 1988). Data from the literature and from field experiments (Bloc et al., 1978; Derieux and Bonhomme, 1982a,b; Sibma, 1987; Alblas et al., 1987; Bignon, 1990; Efdé, 1990) were used to assess the rate of phenological development, the partitioning of assimilates to the plant organs, and the effective growth duration that determines the level of production.

Sowing of maize should occur as early as possible to attain a high level of production because of the limiting duration of the growing season. Earliness of sowing, however, is limited in northern and central EC by the warming of the soil in spring, which mainly depends on the course of air temperature in spring and the soil moisture content. In addition, early sowing allows harvesting of silage maize with a higher dry matter content and a higher grain/straw ratio (Behaeghe et al., 1981; Alblas et al., 1987), which results in improved forage quality and lower storage losses. As, for most areas in the EC, sowing is indicated to occur at the end of April or the beginning of May (Alblas et al., 1987; Bignon, 1990), the sowing date used in the model calculations is set at Day 120, except for Sevilla (southern Spain), for which Day 70 appears to be more appropriate. Emergence of the crop occurs about 2 weeks after sowing.

For the production calculations of silage maize in the EC, four maize varieties were used. They differed only with respect to their rate of phenological development, as determined by temperature sums (Table 1). For locations in the northern and central EC very early and half early varieties were used in the calculations, and for locations

Table 1

Temperature sums $\left({ }^{\circ} \mathrm{C} \times\right.$ days) for phenological development from emergence of silking ( $T$-silk) and from silking to harvest ${ }^{\mathrm{a}}$ ( $T$-harv) for the silage maize varieties used in the model calculations

\begin{tabular}{lll}
\hline Maize variety & $T$-Silk $^{\mathrm{b}}$ & $T$-Harv $^{\mathrm{b}}$ \\
\hline Very early & 695 & 655 \\
Half early & 775 & 700 \\
Half late & 855 & 745 \\
Very late & 935 & 790 \\
\hline
\end{tabular}

${ }^{a}$ Model calculations are stopped at harvest, which corresponds to the moment when the dry matter content in the total crop is about $30 \%$

${ }^{b}$ Sum of temperatures above a base temperature of $6^{\circ} \mathrm{C}$.

Data collected from information from Bloc et al. (1978; 1984), Derieux and Bonhomme (1982a,b), and Bignon (1990). 
in the southern and extremely southern EC, half late and very late varieties were used. If the climate changes, the varieties grown may also change in reality, but in this analysis the varieties used in the calculations remained identical.

The end of the growth simulation for silage maize is determined not by the temperature sum till the end of crop growth, but by the temperature sum till the optimum date for harvest (Table 1). Harvest is assumed to occur at the moment that the dry matter content in the total maize crop is about $30 \%$. This appears to be optimum with respect to forage digestibility and prevention of storage losses during ensilage (Te Velde, 1986; Efdé, 1990).

To calculate $\mathrm{CO}_{2}$ assimilation rates, daily minimum and maximum air temperatures, atmospheric $\mathrm{CO}_{2}$ concentration and solar radiation are required (Goudriaan and Van Laar, 1978). To calculate the components of the water balance, data on daily rainfall, windspeed and vapour pressure are also required. For example, the calculations of potential rates of evaporation and transpiration that are made with the Penman formula require data on radiation, average daily air temperature, vapour pressure and windspeed (Frère and Popov, 1979). Daily weather data for 20 meteorological stations, representative of the main arable land areas in all EC countries (Fig. 1) except Greece (for which no sets of daily weather data were available), were used. For most stations the sets of historical weather data covered a period of 20 years (1966-1985).

To calculate the soil water balance, the soil's infiltration, retention and transport properties must be known. These soil physical characteristics are defined by effective soil depth, soil moisture characteristics (notably soil porosity and volumetric moisture contents at field capacity and wilting point, respectively), maximum infiltration rate or surface runoff fraction, and the hydraulic conductivity of the subsoil. For each meteorological station the main soil types that occur on arable land areas within a radius of $100-150 \mathrm{~km}$ around the station (Fig. 1), were obtained from the soil map of the European Communities (Commission of the European Communities (CEC), 1985). This map gives information per unit on soil type, texture class, characteristics such as gravelliness, stoniness, shallow rocks, etc., and slope gradient. By interpreting this information (mainly based on King and Daroussin (1989) and Reinds et al. (1992)), quantitative terms for use in the simulation model could be obtained - fraction of precipitation lost by surface runoff, maximum effectively rooted soil depth ( $100 \mathrm{~cm}$ or less for maize) and available volumetric moisture content in the soil. Areas with a slope gradient of more than $15 \%$ were left out, being too steep for arable farming. For all soil types the ground water table was assumed to be at such a depth that it does not influence the water balance and that excess water may drain rapidly to the subsoil, so that growth reduction owing to oxygen shortage does not occur.

\subsection{Model validation}

Potential and water-limited total productions were calculated for weather data from Wageningen, Netherlands, over the period 1980-1988. The calculated production was compared with actual results from variety trials that were carried out in the 


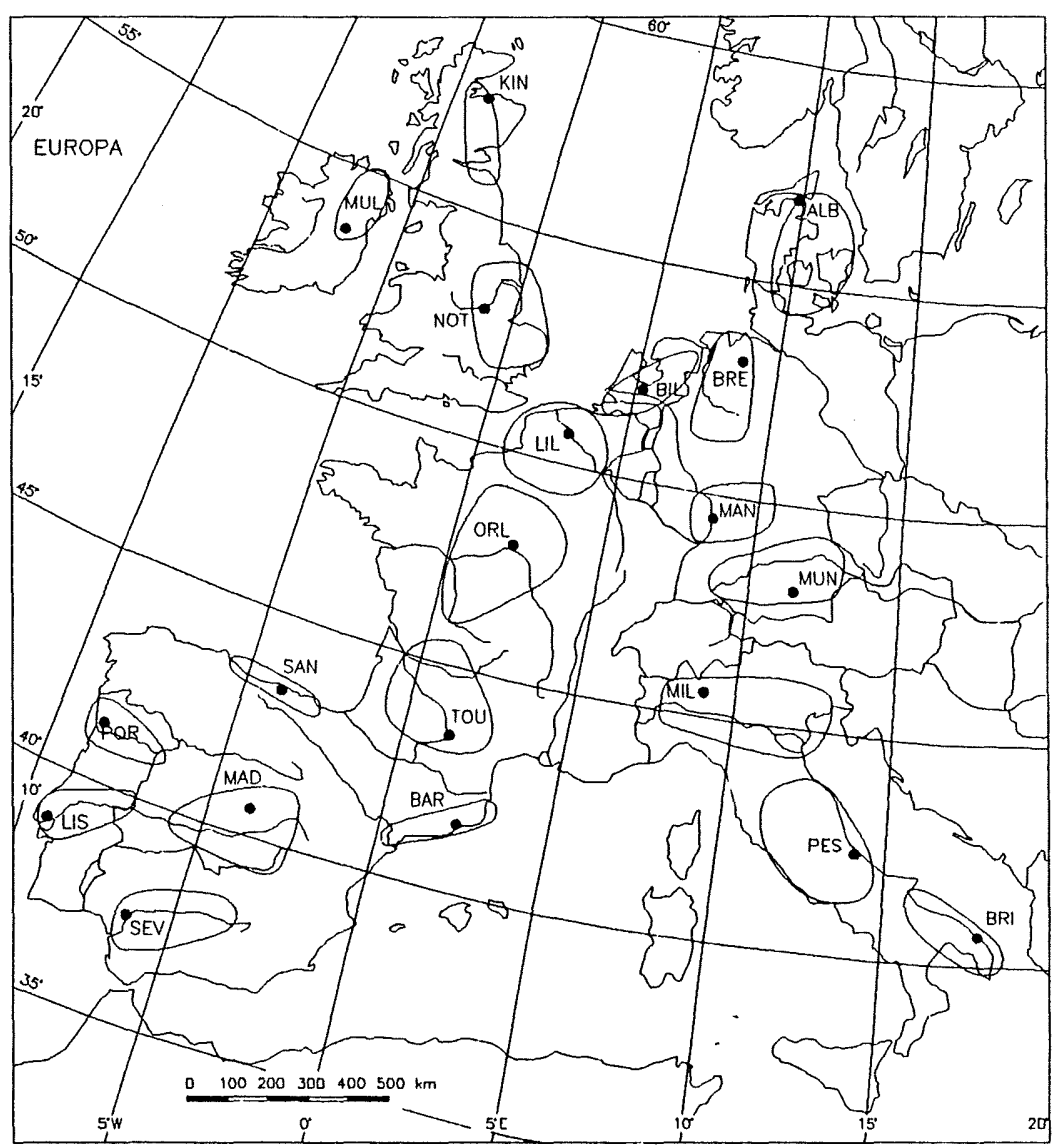

Fig. 1. Sets of historical weather data used for calculating the silage maize production potential in the EC were available for the following meteorological stations: Kinloss and Nottingham in the UK; Mullingar in Ireland; Ålborg in Denmark; de Bilt in the Netherlands; Bremen, Mannheim and München in Germany; Lille, Orleans and Toulouse in France; Santander, Barcelona, Madrid and Sevilla in Spain; Porto and Lisbon in Portugal; Milan, Pescara and Brindisi in Italy. Data for each station can be considered representative of the arable land area around that station, as roughly indicated (exclusive of areas of sea, wetlands, mountains, etc.).

same years in Wageningen and Venray (about $60 \mathrm{~km}$ south-east of Wageningen). In 1982, 1983 and 1986, calculated water-limited production (on soil with $13 \mathrm{~cm}$ maximum available soil moisture) is smaller than the potential production (Fig. 2(B)). This indicates that in these years periods with water shortage might occur. The course of actual maize production in Venray does not show smaller production in 1982, 1983 and 1986 (Fig. 2(A)). This means that in these years water shortage did not occur during the summer, probably because of a relatively high groundwater level in Venray. Hence, these results are comparable with the calculated potential production. On the other hand, actual maize productions in Wageningen are relatively low in 1982, 1983 and 1986 (Fig. 2(B)), which indicates that in these years water shortage has 


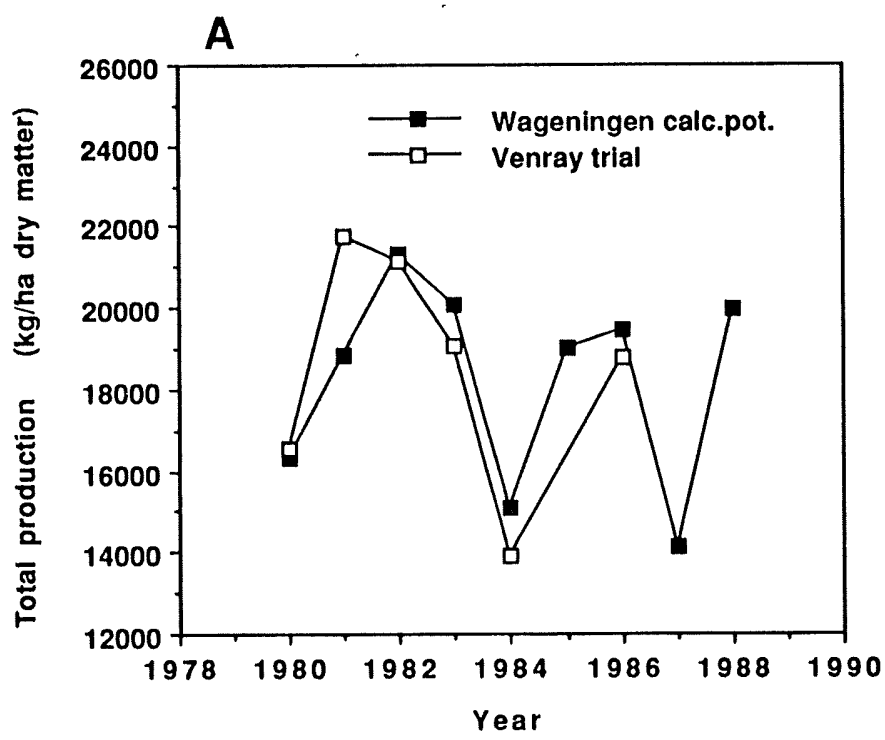

B

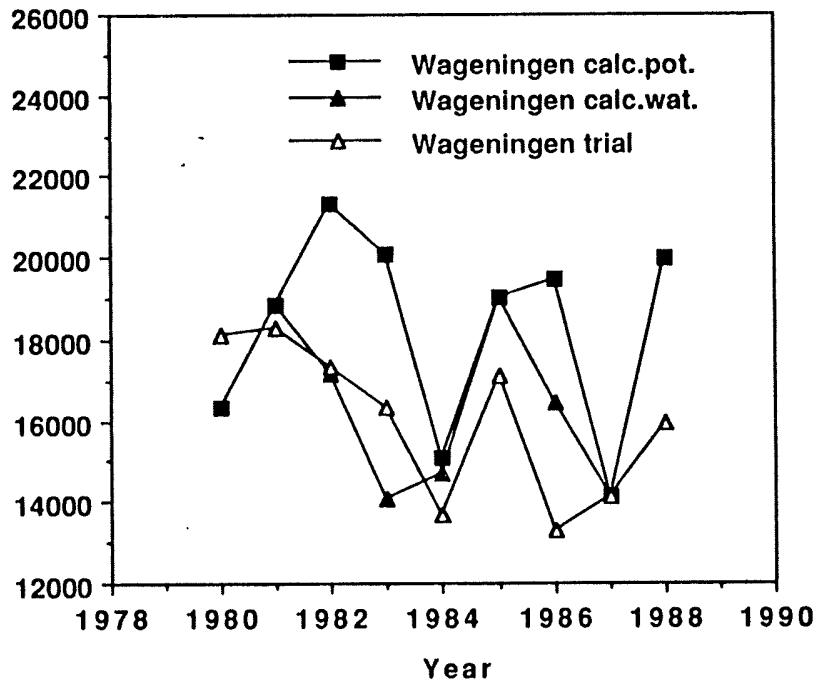

Fig. 2. Potential and water-limited total productions of silage maize calculated for Wageningen, and actual total productions from variety trials (variety Splenda) in Wageningen and Venray, Netherlands.

reduced production and that these actual productions are comparable with calculated water-limited productions.

The comparison shows that the calculated average potential production and the variation in potential production over time are about identical to those actually found 
in the variety trials in Venray (Fig. 2(A)). In years with a relatively high cumulative temperature sum during the growing season, both calculated potential production and actual results from Venray appear to be relatively large. Hence, the variation in cumulative temperature sum mainly causes the large annual variation in potential production, which is a result of the fact that Wageningen and Venray are on the margin of the area where silage maize production is possible. In years with relatively high temperatures and thus a high level of potential production, water-limited production is generally reduced more strongly by water shortage. This is shown both by the actual results from Wageningen and the calculated water-limited productions (Fig. 2(B)), but the correspondence between these actual and calculated productions appears to be slightly less than that for potential production.

\section{Results}

\subsection{Baseline}

Potential total production is about $22000 \mathrm{~kg} \mathrm{ha}^{-1}$ dry matter if temperatures in summer are not too low. Higher production levels are calculated for locations where the level of solar radiation is high during crop growth and the average temperature is relatively low, which results in a long growth period. On the other hand, lower production levels are calculated for locations with higher temperatures and less solar radiation. This explains the relatively large production in Lisbon and Porto and the relatively small production in Brindisi and Madrid (Table 2). If in Brindisi and Porto an identical maize variety was used, the difference in period of crop growth and in production would be even larger. According to the calculated production levels, at present silage maize cannot be grown in Kinloss, UK, and Mullingar, Ireland, during most years because temperatures are too low. At the other locations in the northern EC (Denmark, England, northern Germany and the Netherlands) where temperatures are limiting for maize production to a lesser extent, the potential production level is calculated to be lower (between 17000 and $20000 \mathrm{~kg} \mathrm{ha}^{-1}$ dry matter) than that in the central and southern EC.

Water-limited total production varied widely among locations and also among cultivated soil types. Largest production was found at locations with a relatively

Table 2

Duration of the period of crop growth (days) and the average potential production of silage maize $\left(\mathrm{kg} \mathrm{ha}^{-1}\right.$ dry matter)

\begin{tabular}{lll}
\hline $\begin{array}{l}\text { Location, } \\
\text { maize variety }\end{array}$ & $\begin{array}{l}\text { Period of } \\
\text { crop growth }\end{array}$ & $\begin{array}{l}\text { Total } \\
\text { production }\end{array}$ \\
\hline Madrid, half late & 104 & 22110 \\
Brindisi, very late & 107 & 23270 \\
Lisbon, half late & 111 & 25650 \\
Porto, half early & 119 & 26430 \\
\hline
\end{tabular}




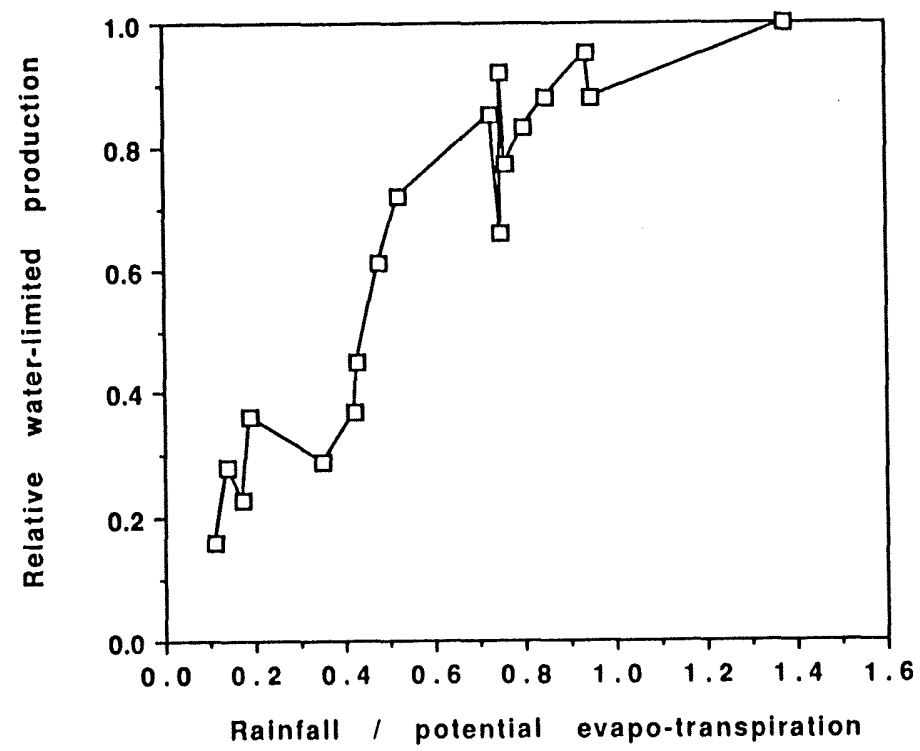

Fig. 3. Water-limited total production of silage maize as fraction of the potential production at 18 locations in the EC in relation to the ratio between precipitation and potential evapotranspiration during the growth period. Productions calculated for historical weather data over a period of 20 years (1966-1985).

high ratio between precipitation and potential evapotranspiration (Fig. 3) and a large amount of available soil moisture. By lowering the amount of available soil moisture (e.g. sandy, gravelly and/or shallow soils instead of deep, loamy or clay soils) waterlimited total production often decreased greatly, as shown in Table 3 for Bremen and Milan. Simultaneously with an increasing risk of drought stress and thus lower average total production, the standard deviation (SD) of the production generally appears to increase, particularly compared with that of the potential production. Hence, the coefficient of variation ( $\mathrm{CV}=\mathrm{SD}$ /average) increases in situations with an increasing risk of drought stress and decreases strongly with increasing application

Table 3

Average values (AV), standard deviations (SD) and coefficients of variation (CV) of potential and waterlimited total productions of silage maize $\left(\mathrm{kg} \mathrm{ha}^{-1}\right.$ dry matter) and the amount of available soil moisture (cm)

\begin{tabular}{|c|c|c|c|c|c|c|c|}
\hline \multirow[t]{2}{*}{ Location } & \multicolumn{3}{|c|}{ Potential production } & \multirow{2}{*}{$\begin{array}{l}\text { Available } \\
\text { soil moisture }\end{array}$} & \multicolumn{3}{|c|}{ Water-limited production } \\
\hline & AV & SD & $\mathrm{CV}$ & & AV & $\mathrm{SD}$ & $\mathrm{CV}$ \\
\hline Bremen & 20350 & 1470 & 0.07 & 6.0 & 15750 & 4260 & 0.27 \\
\hline Bremen & & & & 11.7 & 18420 & 3300 & 0.18 \\
\hline Bremen & & & & 16.0 & 19270 & 2400 & 0.12 \\
\hline Milan & 22240 & 1000 & 0.04 & 3.4 & 9290 & 3460 & 0.37 \\
\hline Milan & & & & 11.2 & 15660 & 3980 & 0.25 \\
\hline Milan & & & & 16.0 & 18150 & 3530 & 0.19 \\
\hline
\end{tabular}


of irrigation water. The $\mathrm{CV}$ is a good indicator of production variability and the risk of a relatively low production. Climate changes may cause changes in the $\mathrm{CV}$, as will be shown in the scenario analyses.

For each location average soil characteristics were calculated from the characteristics of each soil type and in proportion to the relative area of each soil type. Waterlimited total production levels calculated for the average soil characteristics were similar to the average of total production levels calculated for the various soil types for each location, with a difference of $10 \%$ at most. To limit the number of calculations and results, the subsequent sensitivity, scenario and management analyses were done for these average soil characteristics.

\subsection{Sensitivity analyses}

Weather variables that determine crop production directly are solar radiation and temperature. Those that affect the water balance, and hence the duration and degree of drought stress, are rainfall, windspeed, vapour pressure, and again solar radiation and temperature. The atmospheric $\mathrm{CO}_{2}$ concentration also has effects on crop production. These variables were adjusted separately, in a stepwise manner, to gauge the sensitivity of crop production to changing values of each.

Sensitivity analyses were carried out for three locations representative of the main differences in climate in the EC-Kinloss in the UK (cool temperate), Orleans in France (continental), and Brindisi in Italy (Mediterranean). For each location calculations were made using historical weather data over a period of 20 years, with the data for each variable being varied separately. For unchanged weather data, potential production in Kinloss appears to be low, which is a result of too low temperatures in summer for maize production (Table 4). Water-limited production in Orleans is relatively low and in Brindisi very low, which indicates that in many situations irrigation water is required to attain high production.

Table 5 summarizes the sensitivity of potential and water-limited total production to changing values of each weather variable. Potential total production increases with increasing solar radiation (via higher $\mathrm{CO}_{2}$ assimilation rate), and with rising temperatures increases in Kinloss (via higher $\mathrm{CO}_{2}$ assimilation rate) and decreases in Orleans and Brindisi (via shorter growth period). Potential production is not

Table 4

Average potential and water limited total production $\left(\mathrm{kg} \mathrm{ha}^{-1} \mathrm{dry}\right.$ matter) of silage maize at three locations in the EC; productions were established for historical unchanged weather data over a period of 20 years (1966-1985)

\begin{tabular}{lllr}
\hline & Location, maize variety & \\
\cline { 2 - 4 } & Kinloss, & Orleans, \\
very early & very early & $\begin{array}{c}\text { Brindisi, } \\
\text { very late }\end{array}$ \\
\hline Potential production & 11820 & 22630 & 23270 \\
Water-limited production & 11610 & 16320 & 5310 \\
\hline
\end{tabular}


Table 5

Sensitivity of potential (POT) and water-limited (WAT) total productions of silage maize in Kinloss, UK (KIN), Orleans, France (ORL), and Brindisi, Italy (BRI), to increasing values for atmospheric $\mathrm{CO}_{2}$ concentration $(C)$, temperature $(T)$, rainfall $(R)$, solar radiation $(S)$, windspeed $(W)$ and vapour pressure $(V)$ (expressed in relative change in total production per unit change in temperature $\left({ }^{\circ} \mathrm{C}\right)$ or per relative change in one of the other weather variables), and changes in total production (as a percentage of production at current climate) at these locations for specified changes in weather variables

Sensitivity

\begin{tabular}{|c|c|c|c|c|c|c|c|c|c|}
\hline & \multicolumn{3}{|l|}{$C$} & \multicolumn{3}{|l|}{$T$} & \multicolumn{3}{|l|}{$R$} \\
\hline & KIN & ORL & BRI & KIN & ORL & BRI & KIN & ORL & BRI \\
\hline \multirow{4}{*}{$\begin{array}{l}\text { POT } \\
\text { WAT }\end{array}$} & 0.0 & 0.0 & 0.0 & +0.171 & -0.024 & -0.060 & 0.0 & 0.0 & 0.0 \\
\hline & +0.021 & +0.308 & +0.380 & +0.080 & -0.105 & -0.075 & +0.054 & +0.561 & +0.395 \\
\hline & \multicolumn{3}{|l|}{$s$} & \multicolumn{3}{|l|}{$W$} & \multicolumn{3}{|l|}{$V$} \\
\hline & KIN & ORL & BRI & KIN & ORL & BRI & KIN & ORL & BRI \\
\hline POT & +1.058 & +0.723 & +0.622 & 0.0 & 0.0 & 0.0 & 0.0 & 0.0 & 0.0 \\
\hline WAT & +0.961 & +0.089 & -0.077 & -0.070 & -0.314 & -0.188 & +0.156 & +1.226 & +0.663 \\
\hline \multicolumn{10}{|c|}{ Changes (\%) } \\
\hline & \multicolumn{3}{|c|}{$C\left(353-550 \mu \mathrm{mol} \mathrm{mol}^{-1}\right)$} & \multicolumn{3}{|l|}{$T\left(+3^{\circ} \mathrm{C}\right)$} & \multicolumn{3}{|c|}{$R(+30 \%)$} \\
\hline & KIN & ORL & BRI & KIN & ORL & BRI & KIN & ORL & BRI \\
\hline POT & 0 & 0 & 0 & +51 & -7 & -18 & 0 & 0 & 0 \\
\hline \multirow[t]{3}{*}{ WAT } & +1 & +17 & +21 & +24 & -32 & -23 & +2 & +17 & +12 \\
\hline & \multicolumn{3}{|c|}{$S(+10 \%)$} & \multicolumn{3}{|c|}{$W(+30 \%)$} & \multicolumn{3}{|c|}{$V(+10 \%)$} \\
\hline & KIN & ORL & BRI & KIN & ORL & BRI & KIN & ORL & BRI \\
\hline POT & +11 & +7 & +6 & 0 & 0 & 0 & 0 & 0 & 0 \\
\hline WAT & +10 & +1 & -1 & -2 & -9 & -6 & +2 & +12 & +7 \\
\hline
\end{tabular}

influenced by the water balance and is thus insensitive to changes in windspeed, vapour pressure, rainfall and atmospheric $\mathrm{CO}_{2}$ concentration. Water-limited production in Orleans and Brindisi increases with increasing atmospheric $\mathrm{CO}_{2}$, rainfall and vapour pressure, and decreases with increasing temperature and windspeed. The production increases can be explained from the larger water supply (by increase in rainfall) or the larger water use efficiency (by increasing $\mathrm{CO}_{2}$ and vapour pressure). The production decreases are caused by the smaller water use efficiency and the shorter growth period (by rising temperature). The effect of changes in weather variables on the water-limited production appears to be generally less in Brindisi than in Orleans. This is caused by the low amount of rainfall and the resulting very low level of water-limited production in Brindisi (Table 4). In Kinloss production is almost not limited by the water supply. This explains the much smaller, positive 
effects of increasing atmospheric $\mathrm{CO}_{2}$, vapour pressure and rainfall and the much smaller, negative effects of increasing windspeed. Increasing solar radiation causes a higher assimilation rate of the leaves but also a higher rate of evapotranspiration. If water supply is strongly limiting for production (e.g. Brindisi), increasing radiation then results in a lower production. However, for a situation without water limitation (e.g. Kinloss), strong production increases were calculated. As, in reality, the various weather variables do not change to the same extent, sensitivities of potential and water-limited production are also given for specified changes in weather variables (Table 5). This indicates the degree of changes in production that might be expected for a change in climate. The changes in water-limited production appear to differ strongly between situations without (e.g. Kinloss) and with a moderate (e.g. Orleans) to strongly limiting (e.g. Brindisi) water supply.

\subsection{Scenario analyses without direct $\mathrm{CO}_{2}$ effect}

\section{Composite time-dependent scenarios}

Average potential and water-limited total production levels of silage maize and the SD of the productions were calculated for historical weather data that were changed on the basis of Composite Scenario A (based on the 'business-as-usual' emission scenario of Houghton et al. (1990) that applies to a future situation with a coalintensive energy supply, only modest increases in energy use efficiency, continuing

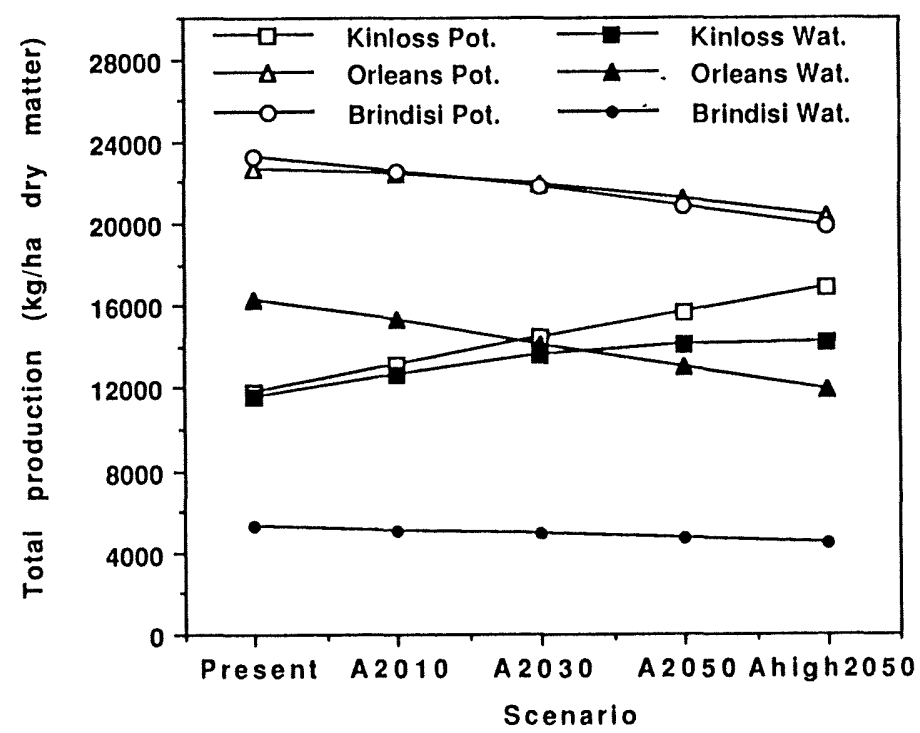

Fig. 4. Average potential (Pot.) and water-limited (Wat.) total production of maize cultivated at current and future climate conditions in Kinloss, Orleans and Brindisi (direct effect of increasing atmospheric $\mathrm{CO}_{2}$ in the future is not taken into account). Production has been established for historical weather data over a period of 20 years (1966-1985), for Composite Scenario A for 2010, 2030 and 2050, and for Composite Scenario A High for 2050. 
deforestation and uncontrolled agricultural emissions of methane and nitrous oxide) for the years 2010, 2030 and 2050, and Composite Scenario A High (high estimate of Scenario A) for the year 2050. These changes, as described by Barrow (1993), were applied on a daily basis over a period of 1 year. For precipitation and temperature the changes were location specific. For solar radiation and vapour pressure only one set of changes was supplied for all locations, and for windspeed no changes could be made (Barrow, 1993).

Potential production in the central and southern EC (e.g. Orleans and Brindisi) will decrease slightly and moderately, respectively, over time as a result of a gradual decrease in the growth period at the rising temperatures (Fig. 4). In the northern EC (e.g. Kinloss) a temperature rise over time results in a higher assimilation rate and longer growth period and hence in a major increase in total production.

Water-limited production in Orleans is about $70 \%$ of the potential production and

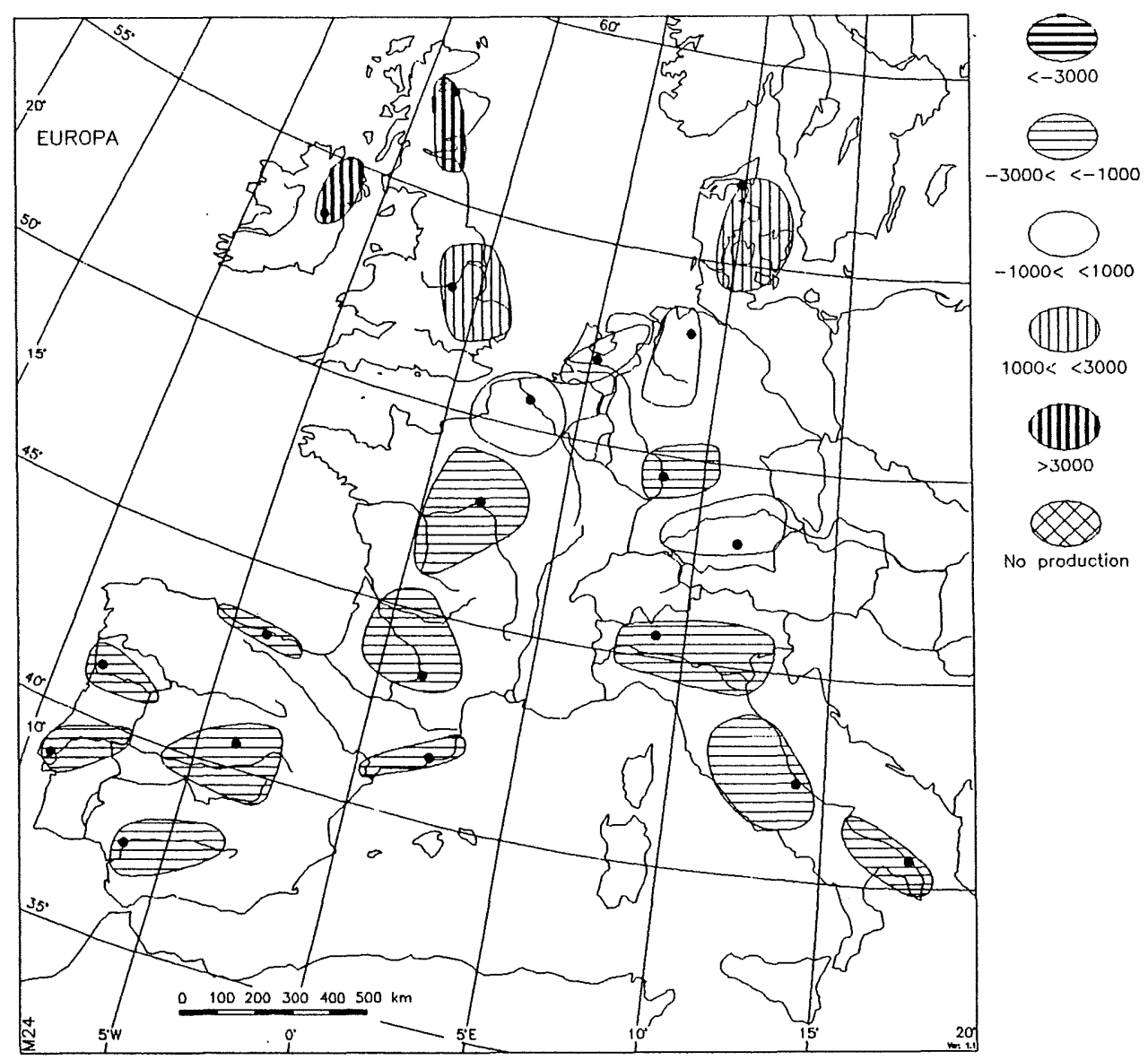

Fig. 5. Changes in potential total production $\left(\mathrm{kg} \mathrm{ha}^{-1}\right.$ dry matter) of silage maize in the main arable land areas in the EC if the weather is changed on the basis of Composite Scenario A for 2050. 
decreases greatly over time, as a result of an increase in periods with drought stress and a shorter growth period (Fig. 4). In Kinloss the water-limited production increases moderately over time, being mainly limited by the temperature, except for 2050 when the water supply becomes limiting. In Brindisi the water-limited production is less than a fourth part of potential production, decreases slightly over time, and depends largely on the application of irrigation water.

Composite Scenario A 2050 gives major increases in potential production in Scotland and Ireland, and moderate increases in Denmark and England (Fig. 5), which are unsuitable or of limited suitability, respectively, for silage maize production at present. From the level of production (Fig. 4) it can be derived that in 2050 only Kinloss will not yet be suitable for silage maize production. For northern

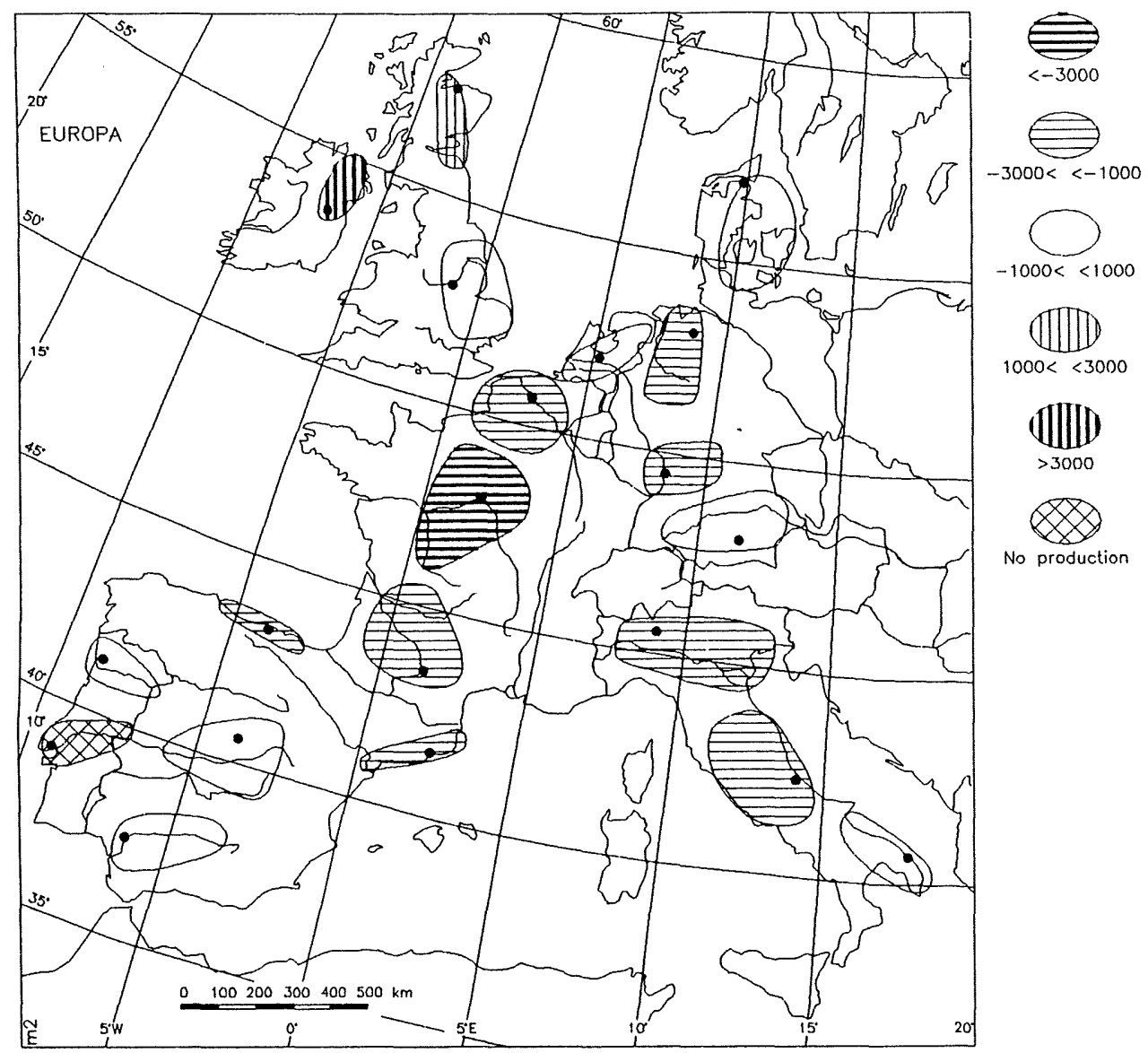

Fig. 6. Changes in water-limited total production $\left(\mathrm{kg} \mathrm{ha}^{-1}\right.$ dry matter) of silage maize in the main arable land areas in the $\mathrm{EC}$ if the weather is changed on the basis of Composite Scenario A for 2050 (direct effect of increased atmospheric $\mathrm{CO}_{2}$ in the future is not taken into account; the class 'no production' for scenario climate is for less than $4000 \mathrm{~kg} \mathrm{ha}^{-1}$ ). 
France, the Netherlands and northern and southern Germany, where silage maize production is extensively cultivated at present, production is calculated to remain identical. Moderate decreases in total production were calculated for the central and southern EC, as a result of the rising temperatures that cause a shorter growth period. This can probably be largely prevented by growing maize varieties with greater temperature sum requirements.

Composite Scenario A 2050 gives moderate and major increases in water-limited production in Scotland and Ireland, respectively (Fig. 6). Productions were calculated to remain identical in England, Denmark, the Netherlands and southern Germany. In the other regions of Germany, in France (except for central France), and in northern and central Italy production appears to decrease moderately. In southern Italy, in central and southern Spain, and in Portugal, where the level of water-limited production at present is very low (Fig. 4), production slightly decreases.

The SD of potential productions in Orleans and Brindisi decreases with time (Table 6). As average potential production decreases with time too, the difference in $\mathrm{CV}$ between scenario and historical climate is very small. In Kinloss SD also decreases with time. The major increase in average production with time, as a result of the increasing temperatures, results in a major decrease in CV. In Orleans SD of water-limited production decreases with time. The moderate decrease in average production with time results in a constant value for CV. In Kinloss SD of waterlimited production increases with time. The moderate increase in average production as a result of increasing temperatures gives generally (except for Scenario A High 2050) an almost constant value for CV. In Brindisi both average water-limited production and SD decrease with time and this results in an almost constant value for CV.

Table 6

Average values (AV), standard deviations (SD) and coefficients of variation (CV) of potential (POT) and water-limited (WAT) total productions $\left(\mathrm{kg} \mathrm{ha}^{-1}\right.$ dry matter) of silage maize established for historical weather data and the same weather data changed on the basis of Composite Scenario A for 2010, 2030 and 2050 and Composite Scenario A High for 2050 (direct effect of increasing $\mathrm{CO}_{2}$ not taken into account)

\begin{tabular}{|c|c|c|c|c|c|c|c|c|c|c|}
\hline \multirow[t]{3}{*}{ Location } & \multirow{2}{*}{\multicolumn{2}{|c|}{$\begin{array}{l}\text { Historical } \\
\text { weather }\end{array}$}} & \multicolumn{8}{|l|}{ Scenario } \\
\hline & & & \multicolumn{2}{|l|}{ A2010 } & \multicolumn{2}{|l|}{ A2030 } & \multicolumn{2}{|l|}{$\mathrm{A} 2050$} & \multicolumn{2}{|l|}{ AHi2050 } \\
\hline & 101 & WAI & POT & WAT & POT & WAT & POT & WAT & POT & WAT \\
\hline Brindisi AV & 23270 & 5310 & 22550 & 5120 & 21750 & 4900 & 20850 & 4680 & 19840 & 4410 \\
\hline Brindisi SD & 1110 & 1700 & 1110 & 1600 & 1060 & 1510 & 1040 & 1430 & 1030 & 1330 \\
\hline Brindisi CV & 0.05 & 0.32 & 0.05 & 0.31 & 0.05 & 0.31 & 0.05 & 0.31 & 0.05 & 0.30 \\
\hline Kinloss AV & 11820 & 11610 & 13080 & 12660 & 14410 & 13570 & 15670 & 14080 & 16920 & 14230 \\
\hline Kinloss SD & 1550 & 1360 & 1400 & 1230 & 1270 & 1430 & 1160 & 1950 & 880 & 2560 \\
\hline Kinloss CV & 0.13 & 0.12 & 0.11 & 0.10 & 0.09 & 0.11 & 0.07 & 0.14 & 0.05 & 0.18 \\
\hline Orleans AV & 22630 & 16320 & 22380 & 15260 & 21900 & 14090 & 21200 & 13000 & 20330 & 11990 \\
\hline Orleans SD & 1520 & 3200 & 1320 & 3060 & 1160 & 2840 & 1160 & 2620 & 1050 & 2390 \\
\hline Orleans CV & 0.07 & 0.20 & 0.06 & 0.20 & 0.05 & 0.20 & 0.05 & 0.20 & 0.05 & 0.20 \\
\hline
\end{tabular}




\section{Individual general circulation model scenarios}

Average potential and water-limited total production levels of silage maize and the standard deviation of the productions were calculated for historical weather data that were changed on the basis of output from three equilibrium $2 \times \mathrm{CO}_{2}$ general circulation models (GCMs), i.e. the Geophysical Fluid Dynamics Laboratory (GFDL), the Goddard Institute for Space Studies (GISS), and the UK Meteorological Office low resolution (UKMO-L) models. These changes, as described by Barrow (1993), were applied on a daily basis over a period of 1 year for each weather variable and were location specific.

Potential total production decreases at almost all locations for the changed weather data, except for locations where at present silage maize production is impossible or marginal because of too low temperatures (Table 7). This production decrease is mainly caused by the higher temperatures which result in a shorter growth period. By growing maize varieties with greater temperature sum requirements this decrease in production can probably be prevented to a large extent. Comparing results for the three GCM scenarios, a lower potential production level is generally calculated for the GFDL and UKMO-L scenarios, which tend to give a greater rise in temperature, than for the GISS scenario. At locations in the northern EC (Table 7: Kinloss) the temperature rise causes major increases in assimilation rate and in length of the growing season, and hence major increases in production. Production of silage maize appears to become an option in the northern EC.

Changes in temperature based on the scenarios influence water-limited production in the same way as they influence potential production (Table 7). In addition, the amount of rainfall may change, and the potential water losses by evapotranspiration may also change, depending on scenario-based changẹs in mainly windspeed, radiation and vapour pressure. The interaction between changes in the weather variables is

Table 7

Average values (AV), standard deviations (SD) and coeffici nts of variation (CV) of potential (POT) and water-limited (WAT) total productions $\left(\mathrm{kg} \mathrm{ha}^{-1}\right.$ dry matter) of silage maize established for historical weather data and the same weather data changed on the basis of the GFDL, GISS and UKMO-L equilibrium $2 \times \mathrm{CO}_{2}$ scenarios (direct effect of increased $\mathrm{CO}_{2}$ not taken into account)

\begin{tabular}{|c|c|c|c|c|c|c|c|c|}
\hline \multirow[t]{3}{*}{ Location } & \multirow{2}{*}{\multicolumn{2}{|c|}{$\begin{array}{l}\text { Historical } \\
\text { weather }\end{array}$}} & \multicolumn{6}{|l|}{ Scenario } \\
\hline & & & \multicolumn{2}{|l|}{ GFDL } & \multicolumn{2}{|l|}{ GISS } & \multicolumn{2}{|l|}{ UKMO } \\
\hline & POT & WAT & POT & WAT & POT & WAT & POT & WAT \\
\hline Brindisi AV & 23270 & 5310 & 17880 & 4510 & 18980 & 4150 & 16660 & 3980 \\
\hline Brindisi SD & 1110 & 1700 & 1040 & 1370 & 1090 & 1260 & 1050 & 1200 \\
\hline Brindisi CV & 0.05 & 0.32 & 0.06 & 0.30 & 0.06 & 0.30 & 0.06 & 0.30 \\
\hline Kinloss AV & 11820 & 11610 & 15040 & 9770 & 17190 & 15680 & 16970 & 13680 \\
\hline Kinloss SD & 1550 & 1360 & 910 & 2940 & 970 & 2290 & 1020 & 2870 \\
\hline Kinloss CV & 0.13 & 0.12 & 0.06 & 0.30 & 0.06 & 0.15 & 0.06 & 0.21 \\
\hline Orleans AV & 22630 & 16320 & 17040 & 7010 & 18980 & 13360 & 17770 & 11650 \\
\hline Orleans SD & 1520 & 3200 & 1130 & 930 & 1030 & 2570 & 1270 & 2820 \\
\hline Orleans CV & 0.07 & 0.20 & 0.07 & 0.13 & 0.05 & 0.19 & 0.07 & 0.2 \\
\hline
\end{tabular}


very complex and besides, the changes appear to vary considerably among locations and over the year. For the GFDL scenario, water limitation appears to increase strongly, which causes much lower productions, even in the northern EC (Table 7: Kinloss). For the GISS scenario the water limitation remains almost identical to that at present. This scenario gives moderate decreases in production, mainly as a result of rising temperatures, for most locations in Europe except for the northern EC, for which production increases were calculated. The UKMO-L scenario also gives decreases in production for most locations in the EC except for the northern EC.

The SD of potential production differs among the three scenarios to a limited extent and is lower than that for historical climate (Table 7). As average potential production also decreases as a result of scenario climate changes, differences in CV between both scenario and historical climate and between the three scenarios appear to be negligible. Only at Kinloss is the CV much lower for scenario climate than for historical climate, as temperature rise results in a much higher level of average production. Average water-limited production in Orleans appears to decrease greatly with climate change, as a result of rising temperatures and increasing periods with drought stress (particularly severe water shortage for the GFDL scenario). As SD decreases to about the same extent, the values for $\mathrm{CV}$ remain almost identical. In the southern EC (e.g. Brindisi) water-limited production is very low, both for present and for scenario climate. This results in a high $\mathrm{CV}$, which is identical for both historical climate and the three scenario climates. In Kinloss, where temperatures at present are strongly limiting for production, average water-limited production appears to increase generally with climate change, except for the GFDL scenario with its strongly increased water limitation. The $\mathrm{CV}$ increases in correspondence to the degree of water limitation in Kinloss, which appears to vary considerably among the three scenarios (e.g. highest CV for the GFDL scenario).

\subsection{Scenario analyses with direct $\mathrm{CO}_{2}$ effect}

\section{Composite time-dependent scenarios}

In these analyses the direct effect of increasing atmospheric $\mathrm{CO}_{2}$ was taken into account. The $\mathrm{CO}_{2}$ assimilation rate of the leaves of a maize crop does not increase with increasing atmospheric $\mathrm{CO}_{2}$, and hence the potential production level remains the same. Increasing $\mathrm{CO}_{2}$ results in a lower transpiration rate and thus in a higher

Table 8

Atmospheric $\mathrm{CO}_{2}$ concentration $\left(\mu \mathrm{mol} \mathrm{mol}^{-1}\right)$ projected for different emission scenarios and years (Houghton et al., 1990; Barrow, 1993)

\begin{tabular}{lllll}
\hline Scenario & Present & Year & & \\
\cline { 3 - 4 } & & 2010 & 2030 & 2050 \\
\hline$\overline{\text { A }}$ & 353 & & & \\
A High & & 400 & 458 & 539 \\
\hline
\end{tabular}


level of water-limited total production. Consequently, only the water-limited productions differ from those without increased atmospheric $\mathrm{CO}_{2}$ and will be discussed here. Calculations were carried out for historical weather data changed on the basis of the Composite Scenarios A and A High and for $\mathrm{CO}_{2}$ concentrations projected for the same scenarios and years (Table 8).

Water-limited production in Orleans remains almost constant with time (Fig. 7). If the direct effect of increasing atmospheric $\mathrm{CO}_{2}$ on crop transpiration is not taken into account, a major decrease in production is found. Scenario A High gives for 2050 a greater temperature rise, which causes a larger decrease in production. Actual temperatures in Kinloss are strongly limiting for maize production. Hence, rising temperatures with time according to the scenarios result in moderate and major increases in production for situations without and with direct $\mathrm{CO}_{2}$ effect, respectively (Fig. 7). In Brindisi water supply during the summer is limited and results in a very low production level that remains almost constant with time. For the other locations in the EC comparable changes in water-limited production as a result of the scenario climate changes were calculated. Scenario A gives for 2050 moderate to major increases in water-limited production for the northern EC, almost constant production for the central EC and an almost constant but very low production for the southern EC (Fig. 8).

\section{Individual GCM scenarios}

In these analyses the effects of the GFDL, GISS and UKMO-L equilibrium $2 \times \mathrm{CO}_{2}$ scenarios and increased atmospheric $\mathrm{CO}_{2}$ concentration (from 353 to

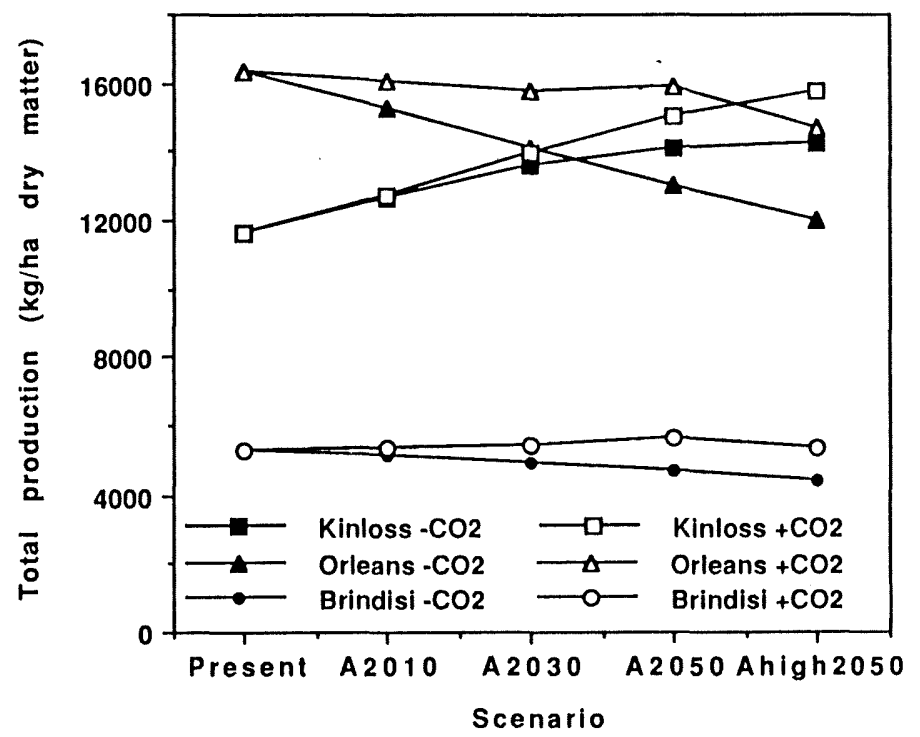

Fig. 7. Average water-limited total production of silage maize cultivated at current and future climate conditions in Kinloss, Orleans and Brindisi, without $\left(-\mathrm{CO}_{2}\right)$ and with $\left(+\mathrm{CO}_{2}\right)$ the direct effect of increasing atmospheric $\mathrm{CO}_{2}$ in future. Production has been established for historical weather data over a period of 20 years (1966-1985), for Composite Scenario A for 2010, 2030 and 2050, and for Composite Scenario A High for 2050 . 


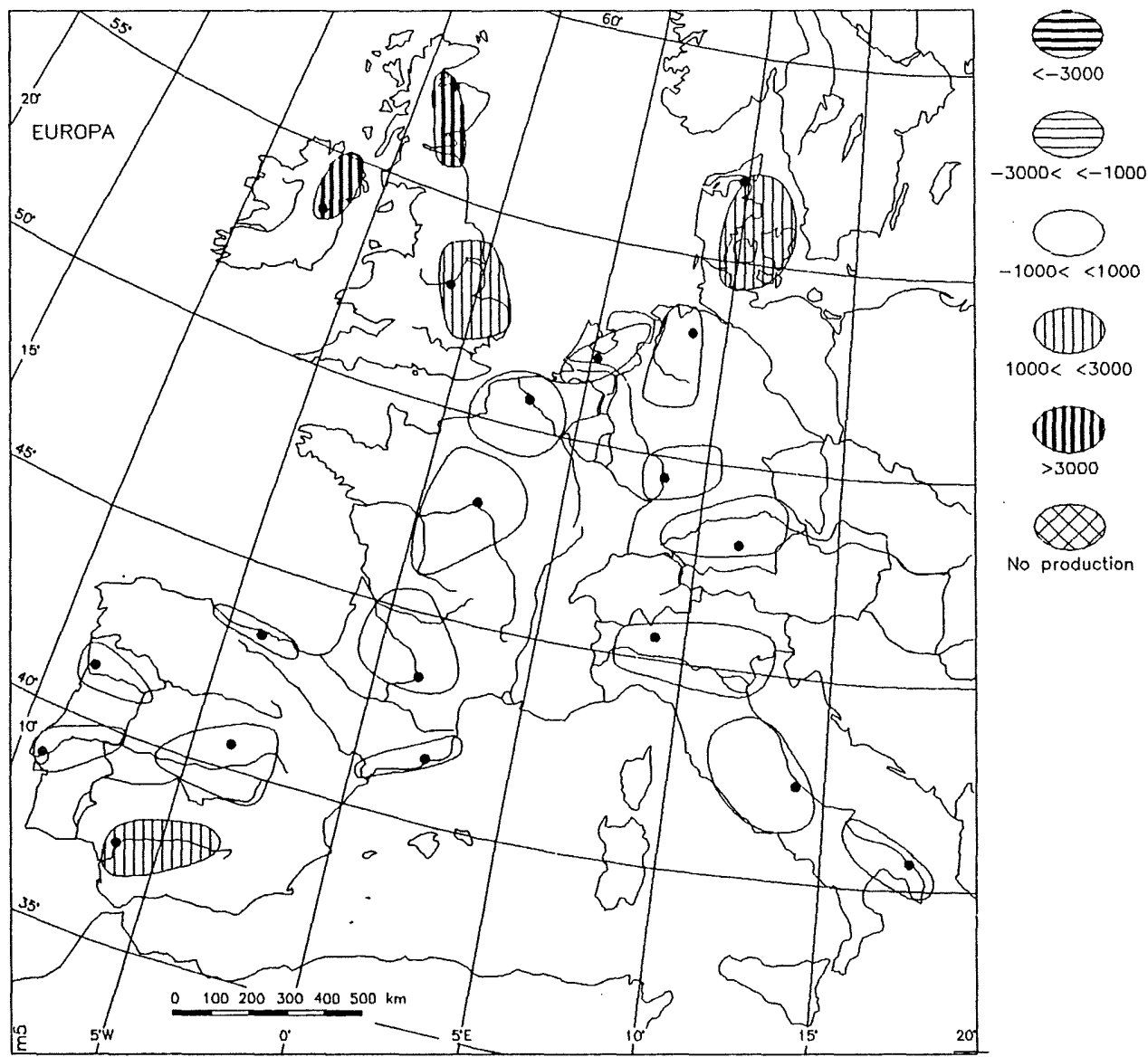

Fig. 8. Changes in water-limited total production $\left(\mathrm{kg} \mathrm{ha}^{-1}\right.$ dry matter) of silage maize in the main arable land areas in the EC if the weather is changed on the basis of the Composite Scenario A for 2050 and the direct effect of increased atmospheric $\mathrm{CO}_{2}$ is taken into account (the class 'no production' for scenario climate is for less than $4000 \mathrm{~kg} \mathrm{ha}^{-1}$ ).

$560 \mu \mathrm{mol} \mathrm{mol}^{-1}$ ) were taken into account. Only water-limited productions will be discussed here. Increased atmospheric $\mathrm{CO}_{2}$ results in a higher level of water-limited production, which can be explained by the lower transpiration rate and shortened periods with drought stress. This decrease in drought stress is clearly indicated by the increased ratio between water-limited and potential production with increased atmospheric $\mathrm{CO}_{2}$ (Table 9). In the northern EC (Table 9: Kinloss) climate change according to the GISS and UKMO-L scenarios results in major increases in production, even at the current $\mathrm{CO}_{2}$ concentration. For the GFDL scenario, production remains identical, owing to the strongly limiting water supply. At current atmospheric $\mathrm{CO}_{2}$ this scenario gives a decrease in production. In the central EC (Table 9: Orleans) climate change according to the GISS and UKMO-L scenarios results in no change 
Table 9

Average potential (POT) and water-limited (WAT) total productions $\left(\mathrm{kg} \mathrm{ha}^{-1} \mathrm{dry}\right.$ matter) of silage maize established for historical weather data and the same weather data changed on the basis of the GFDL, GISS and UKMO-L equilibrium $2 \times \mathrm{CO}_{2}$ scenarios; direct effect of actual $\left(353 \mu \mathrm{mol} \mathrm{mol}^{-1}\right)$ and increased atmospheric $\mathrm{CO}_{2}$ concentrations $\left(560 \mu \mathrm{mol} \mathrm{mol}^{-1}\right)$ is taken into account

\begin{tabular}{lcrrr}
\hline \multirow{2}{*}{$\begin{array}{l}\text { Location, } \\
\mathrm{CO}_{2} \text { concentration }\end{array}$} & $\begin{array}{l}\text { Historical } \\
\text { weather }\end{array}$ & \multicolumn{2}{l}{ Scenario } & \\
\cline { 3 - 5 } & & GFDL & GISS & UKMO \\
\hline Brindisi POT & 23270 & 17880 & 18980 & 16660 \\
Brindisi WAT $\mathrm{CO}_{2} 353$ & 5310 & 4510 & 4150 & 3980 \\
Brindisi WAT $\mathrm{CO}_{2} 560$ & & 5530 & 5140 & 4950 \\
Kinloss POT & 11820 & 15040 & 17190 & 16970 \\
Kinloss WAT $\mathrm{CO}_{2} 353$ & 11610 & 9770 & 15680 & 13680 \\
Kinloss WAT $\mathrm{CO}_{2} 560$ & & 11590 & 16690 & 15500 \\
Orleans POT & 22630 & 17040 & 18980 & 17770 \\
Orleans WAT $\mathrm{CO}_{2} 353$ & 16320 & 7010 & 13360 & 11650 \\
Orleans WAT $\mathrm{CO}_{2} 560$ & & 8470 & 15850 & 14050 \\
\hline
\end{tabular}

and a moderate decrease in water-limited production, respectively, and in major decreases in production if atmospheric $\mathrm{CO}_{2}$ remains at the current level. For the GFDL scenario, the water supply is limiting to such extent that even at increased $\mathrm{CO}_{2}$ production decreases strongly. In the southern EC (Table 9: Brindisi) the amount of rainfall is low, and hence water-limited production is very low for both historical climate and scenario climates. Here climate change results in no change to a moderate decrease in production. The low levels of production indicate that application of irrigation water is required to allow maize production in the southern EC, both at current and at scenario climate conditions.

The SD of water-limited total production in Orleans decreases slightly for the composite climate change scenarios and moderately to strongly for the individual scenarios (Table 10). As the average production for the composite scenarios also decreases slightly with time, the CV does not change with time. For the individual scenarios slight to major decreases in average production were calculated, which result in no change to a moderate decrease in $\mathrm{CV}$. These values calculated for the

Table 10

Average values (AV), standard deviations (SD) and coefficients of variation (CV) of water-limited total productions $\left(\mathrm{kg} \mathrm{ha}^{-1}\right.$ dry matter) of silage maize in Orleans, established for historical weather data (HIST) and the same weather data changed on the basis of Composite Scenario A for 2010, 2030 and 2050, Composite Scenario A High for 2050, and GFDL, GISS and UKMO-L equilibrium $2 \times \mathrm{CO}_{2}$ scenarios, with direct effect of increased $\mathrm{CO}_{2}$

\begin{tabular}{|c|c|c|c|c|c|c|c|c|}
\hline & \multirow[t]{2}{*}{ HIST } & \multicolumn{4}{|c|}{ Composite scenarios } & \multicolumn{3}{|c|}{ Individual scenarios } \\
\hline & & A2010 & A2030 & $\mathrm{A} 2050$ & AHI2050 & GFDL & GISS & UKMO \\
\hline $\mathrm{AV}$ & 16320 & 16030 & 15780 & 15910 & 14640 & 8470 & 15850 & 14050 \\
\hline SD & 3200 & 3180 & 3140 & 3070 & 2830 & 1080 & 2480 & 2790 \\
\hline $\mathrm{CV}$ & 0.20 & 0.20 & 0.20 & 0.19 & 0.19 & 0.13 & 0.16 & 0.20 \\
\hline
\end{tabular}


$\mathrm{CV}$ appear to be slightly lower than those given in Tables 6 and 7 for a situation without direct effect of increased $\mathrm{CO}_{2}$.

\subsection{Management analyses}

If climate changes, current crop management may be ill adapted to the new conditions. For example, for US agriculture this was analysed with the Erosion Productivity Impact Calculation (EPIC) model (Easterling et al., 1992a,b). For the EC a number of management responses and their potential usefulness in adapting to the adverse effects of climate change were evaluated in the present study. First, total productions were calculated for varieties differing with respect to their temperature sum requirements for phenological development. Second, the impact of changes in sowing date on the production level were analysed.

\section{Crop temperature sums}

The interactions between the temperature sum required for crop development and the effects of climate change and increasing atmospheric $\mathrm{CO}_{2}$ were determined for three locations, i.e. Kinloss, Orleans and Brindisi. It was assumed that, compared with the main maize varieties grown at present, plant breeding might be able to produce varieties requiring $10 \%$ greater or $10 \%$ smaller temperature sums $\left({ }^{\circ} \mathrm{C} \times\right.$ days) from emergence to silking and from silking to harvest. For the average maize variety grown at present and for these artificially constructed maize varieties, average total production was calculated for historical weather data, for the Composite Scenario A for 2050, both without and with the direct effect of increased atmospheric $\mathrm{CO}_{2}$, and for the Composite Scenario A High for 2050 with the direct $\mathrm{CO}_{2}$ effect. For both potential and water-limited production levels temperature sums from emergence to silking ( $T$-silk) and from silking to harvest ( $T$-harv) that gave highest productions in these analyses for the three locations are summarized in Table 11.

Table 11

Optimum crop temperature sums (as a percentage of average temperature sums for present varieties) from emergence to silking ( $T$-silk) and from silking to harvest ( $T$-harv) for Kinloss, Orleans and Brindisi, and both for historical and scenario weather data

\begin{tabular}{|c|c|c|}
\hline Weather & $\begin{array}{l}\text { Potential production } \\
(T \text {-silk and } T \text {-harv })^{\mathrm{a}}\end{array}$ & $\begin{array}{l}\text { Water-limited production } \\
(T \text {-silk and } T \text {-harv })^{\mathrm{a}}\end{array}$ \\
\hline Historical weather & $\begin{array}{l}110 \% \& 110 \%, 100 \% \& 110 \% \\
110 \% \& 100 \%{ }^{b}\end{array}$ & $\begin{array}{r}100 \% \& 110 \%, 110 \% \& 110 \% \\
90 \% \& 100 \%{ }^{c}, 90 \% \& 90 \%{ }^{c}\end{array}$ \\
\hline Scenario A2050 & $\begin{array}{l}110 \% \& 110 \%, 100 \% \& 110 \% \\
110 \% \& 100 \%{ }^{c}\end{array}$ & $\begin{array}{r}100 \% \& 110 \%, 110 \% \& \& 110 \% \\
90 \% \& 100 \%^{\mathrm{c}}, 90 \% \& 90 \%{ }^{\mathrm{c}}\end{array}$ \\
\hline Scenario $\mathrm{A} 2050+\mathrm{CO}_{2}$ effect & $\begin{array}{l}110 \% \& 110 \%, 100 \% \& 110 \% \\
110 \% \& 100 \%{ }^{c}\end{array}$ & $\begin{array}{r}100 \% \& 110 \%, 110 \% \& 110 \% \\
90 \% \& 100 \%{ }^{\mathrm{c}}, 90 \% \& 90 \%{ }^{\mathrm{c}}\end{array}$ \\
\hline Scenario A High $2050+\mathrm{CO}_{2}$ effect & $\begin{array}{l}110 \% \& 110 \%, 100 \% \& 110 \% \\
110 \% \& 100 \%{ }^{c}\end{array}$ & $\begin{array}{r}100 \% \& 110 \%, 110 \% \& 110 \% \\
90 \% \& 100 \%{ }^{\mathrm{c}}, 90 \% \& 90 \%{ }^{\mathrm{c}},\end{array}$ \\
\hline
\end{tabular}

\footnotetext{
${ }^{a}$ Best temperature sums indicated first (starting from the left side), followed by second best sums

${ }^{b}$ Only in Kinloss and Brindisi.

${ }^{c}$ Only in Brindisi.
} 
From these results it can be concluded that the largest potential production in both present and scenario climate will be attained with maize varieties that need greater temperature sums for vegetative growth and/or grain filling and hence have a longer growth period. Highest water-limited productions in both projected future and current climate conditions will also be attained with maize varieties that have a relatively long growth period. Only in the case where water supply becomes strongly limiting for production (e.g. Brindisi) will a shorter growth period result in a higher (but still very low) production.

\section{Sowing date}

The interactions between sowing date and the effects of climate change and increased atmospheric $\mathrm{CO}_{2}$ were determined for Kinloss and Orleans. For sowing dates varying between Day 60 and 150, average total production was calculated for historical weather data, for the Composite Scenario A for 2050, both without and with the direct effect of increased atmospheric $\mathrm{CO}_{2}$, and for the Composite Scenario A High for 2050 with the direct $\mathrm{CO}_{2}$ effect.

Potential production decreases if sowing is shifted to a relatively late date (Fig. 9). For the historical climate in Orleans, sowing dates before Day 105 result in a lower leaf area and, because of the reduced light interception, in a lower production level. Sowing dates later than Day 120 also result in a lower production, owing to the lower amounts of solar radiation (because of shorter days and lower solar altitude) at the end of the summer and the reduced growth duration. In Kinloss a sowing date

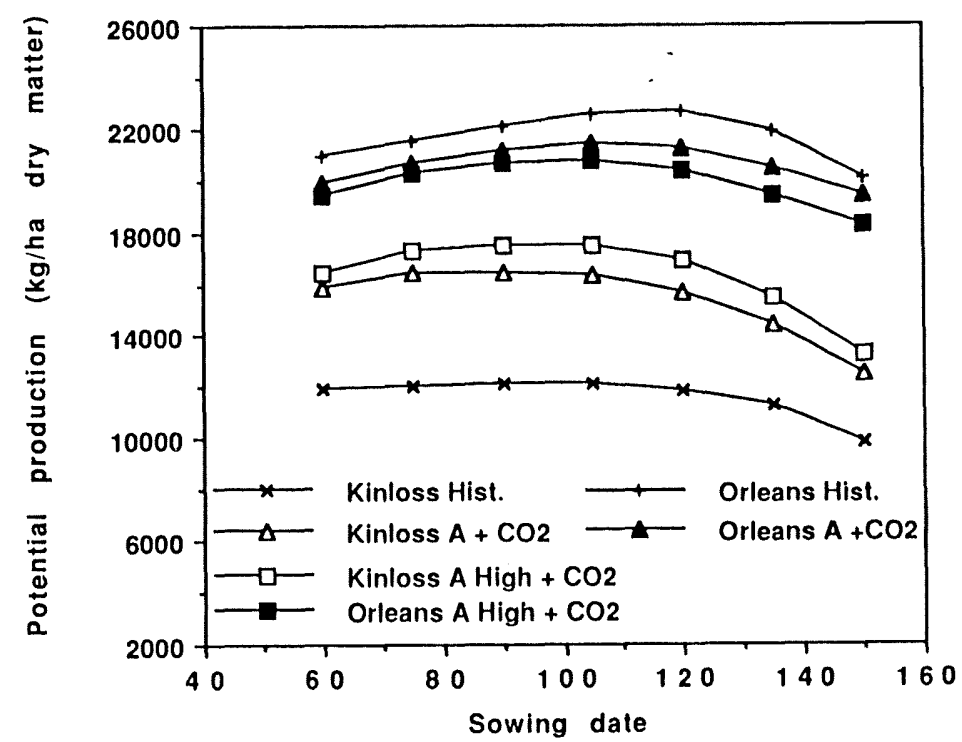

Fig. 9. Sensitivity to changes in sowing date of the average potential total production of silage maize cultivated in Kinloss and Orleans. Production has been established for historical weather data (Hist.), Composite Scenario $A$ for 2050 with direct $\mathrm{CO}_{2}$ effect $\left(\mathrm{A}+\mathrm{CO}_{2}\right)$, and for Composite Scenario $\mathrm{A}$ High for 2050 with direct $\mathrm{CO}_{2}$ effect $\left(\mathrm{A} \mathrm{High}+\mathrm{CO}_{2}\right)$. 


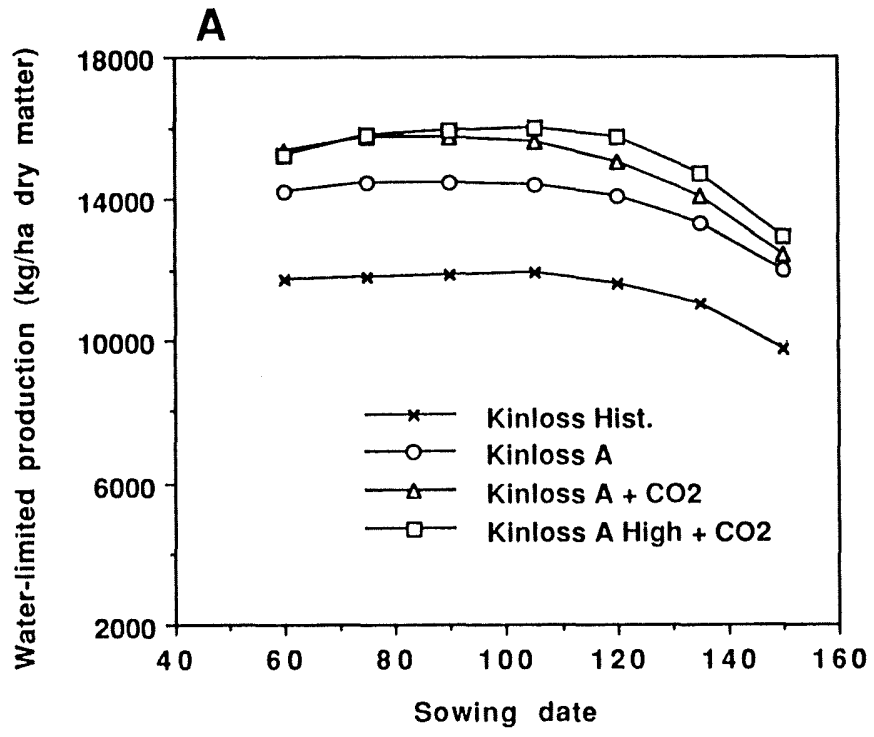

B

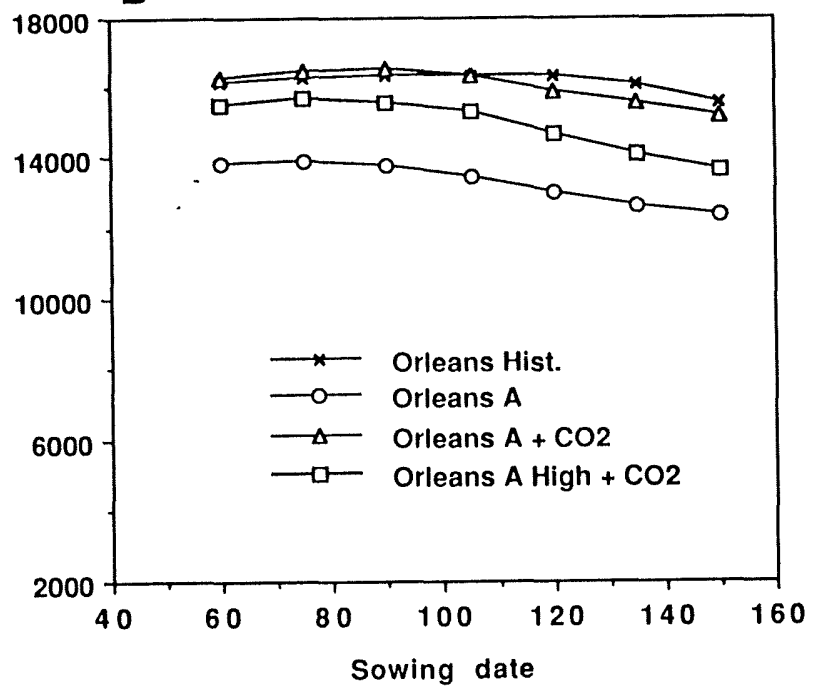

Fig. 10. Sensitivity to changes in sowing date of the average water-limited total production of silage maize cultivated in Kinloss (A) and Orleans (B). Production has been established for historical weather data (Hist.), Composite Scenario $A$ for 2050 , both without (A) and with direct $\mathrm{CO}_{2}$ effect $\left(\mathrm{A}+\mathrm{CO}_{2}\right)$, and for Composite Scenario A High for 2050 with direct $\mathrm{CO}_{2}$ effect $\left(\mathrm{A} \mathrm{High}+\mathrm{CO}_{2}\right)$. 
between Days 90 and 105 appears to be optimum for potential production. Sowing at a later date results in a shorter growth duration and hence in a lower production level. In Orleans at changed climates according to Scenarios A and A High for 2050, sowing should not occur much later than Day 120 and Day 105, respectively, but also not much earlier than Day 90. The level of production in Orleans is lower than that for historical climate as a result of the shorter growth duration (caused by the higher temperatures). In Kinloss, scenario climate results in a higher level of production (because of higher assimilation rate at the higher temperatures). As the length of the growing season is rather short for silage maize, highest production is found at an early sowing date between Days 90 and 105.

Water-limited production also decreases if sowing is shifted to a later date (Fig. 10). The effects discussed above for potential production apply in this case too. In addition, delayed sowing results in postponement of the growth period and owing to this, generally in a lower amount of crop-available rainfall. Hence, in Orleans sowing should occur not later than Day 120 for historical climate and not later than Day 105 for scenario climate. For the scenario where the direct effect of increased $\mathrm{CO}_{2}$ is not taken into account, the production level is about $2800 \mathrm{~kg} \mathrm{ha}^{-1}$ lower as a result of the higher level of crop transpiration (Fig. 10(B)), and the sowing date should be advanced to Day 90 (because of more severe water stress). In Kinloss a delay in sowing date, both for historical and scenario climate, results in a lower production level (Fig. 10(A)). As water supply does not play a major role in this effect (e.g. the level of water-limited production is almost identical to that of potential production), optimum sowing dates are identical to those for potential production.

A very early date of sowing results in a long period of time between sowing and emergence. In this case, plants may, during emergence and initial growth, be affected severely by fungi and unfavourable growing conditions. In this way the positive effect of a very early date of sowing may be undone completely.

\section{Conclusions}

Sensitivity analyses show that potential production of silage maize increases with increasing solar radiation, and, with rising temperatures, increases in the northern EC and decreases in the central and southern EC. Water-limited production appears to increase with increasing atmospheric $\mathrm{CO}_{2}$, vapour pressure and rainfall, to remain identical with increasing solar radiation, and to decrease with increasing windspeed and rising temperature. In the northern EC, where the current low temperatures and not the water supply are mainly limiting for the production level, the sensitivities of potential and water-limited production are almost identical.

Increasing concentrations of greenhouse gases in the atmosphere may cause changes in climate. Various climate change scenarios appear to yield considerably different changes in production, both for each location and for the $\mathrm{EC}$ as a whole. For example, for the equilibrium $2 \times \mathrm{CO}_{2}$ scenarios (without direct effect of $\mathrm{CO}_{2}$ ), the average potential production of silage maize in Orleans decreases by $3700 \mathrm{~kg} \mathrm{ha}^{-1}$, $5600 \mathrm{~kg} \mathrm{ha}^{-1}$ and $4900 \mathrm{~kg} \mathrm{ha}^{-1}$ dry matter for the GISS, GFDL and UKMO-L 
scenarios, respectively, and the average water-limited production in Orleans decreases by $9300 \mathrm{~kg} \mathrm{ha}^{-1}, 3000 \mathrm{~kg} \mathrm{ha}^{-1}$ and $4700 \mathrm{~kg} \mathrm{ha}^{-1}$ dry matter for the GFDL, GISS and UKMO-L scenarios, respectively.

The direct effect of increasing atmospheric $\mathrm{CO}_{2}$ on water-limited silage maize production appears to be considerable in comparison with the effects of climate change. If both effects are taken into account, the average water-limited total production of maize in Orleans may decrease by $7900 \mathrm{~kg} \mathrm{ha}^{-1}, 500 \mathrm{~kg} \mathrm{ha}^{-1}$ and $2300 \mathrm{~kg} \mathrm{ha}^{-1}$ dry matter for the GFDL, GISS and UKMO-L scenarios, respectively.

In both present and scenario climate the highest level of potential production will generally be attained with maize varieties that have greater temperature sum requirements for vegetative growth and/or grain filling and hence have a longer growth period. Highest water-limited production in both current and scenario climate conditions will also be attained with maize varieties that have a relatively long growth period. Only if the water supply becomes strongly limiting for production will a shorter growth period result in a higher (but still very low) production.

Highest level of potential production in the central $\mathrm{EC}$ will be attained if at current climate sowing does not occur much later than Day 120 and at changed climate, on the basis of Composite Scenarios A and A High for 2050, sowing does not occur much later than Day 120 and Day 105, respectively. In the northern EC, both at present and changed climate the date of sowing should not be much later than Day 105, as the length of the growing season in the northern EC is strongly limiting for production. For highest water-limited production at present and scenario climate in the central EC, sowing should occur not much later than Days 120 and 105, respectively, and even earlier (Day 90) if the direct effect of increased $\mathrm{CO}_{2}$ is not taken into account. In the northern EC, sowing at both present and changed climate should not occur much later than Day 105.

For almost all regions in the EC, changed climates as based on the composite and individual scenarios appear to yield a $\mathrm{CV}$ for potential production that is almost equal to that at current climate. For climate change without direct $\mathrm{CO}_{2}$ effect, the $\mathrm{CV}$ of water-limited production remains identical to the present value, and for climate change with direct $\mathrm{CO}_{2}$ effect, the $\mathrm{CV}$ remains the same or slightly decreases. A considerable decrease in $\mathrm{CV}$ can be attained by reducing the risk of drought stress by application of irrigation water.

\section{Acknowledgements}

Many thanks are due to J. Goudriaan (Department of Theoretical Production Ecology, Wageningen Agricultural University), G.J. Kenny, M.L. Parry and P.A. Harrison (Environmental Change Unit, University of Oxford) for support, project management and valuable comments, to E.M. Barrow (Climatic Research Unit, University of East Anglia, Norwich) for providing the climate change scenarios, and to the Environmental Change Unit (University of Oxford) for providing the weather data.

This paper is based on a study that formed part of an EC-funded EPOCH project 
(Contract EPOC-CT90-0031 (TSTS)). A complete report on this study can be obtained from the authors. Results from the EPOCH project have been given in a final report to the EC (Kenny et al., 1993) and in a special issue of the European Journal of Agronomy (1993), where, for example, the results of a similar analysis on the effects of climate changes on the winter wheat production in the EC were discussed (Wolf, 1993).

\section{References}

Alblas, J., Boekel, P. and van der Beek, M.A., 1987. Gewaseisen. In: Themadag 'Werkbaarheid en tijdigheid'. PAGV-verslag 64, Lelystad, Netherlands, pp. 1-20.

Barrow, E.M., 1993. Scenarios of climate change for the European Community. Eur. J. Agron., 2: 247-260.

Behaeghe, T., van Bockstaele, E. and de Baets, A., 1981. Maïs als ruwvoederteelt. 4. Belang van de plantdichtheid, de zaaidatum, de oogstdatum en de eventuele rijenbemesting bij maïsteelt. Samenvatting van recente proefresultaten. Landbouwtijdschrift, 34(3): 573-587.

Bignon, J., 1990. Agrométéorologie et physiologie du mais grain dans la Communauté Européenne. Commission of the European Communities, EUR 13041, Luxembourg, 194 pp.

Bloc, D., Desvignes, P., Gerbier, N. and Remois, P., 1978. Contribution à l'étude agroclimatologique du mais en France. Association Générale des Producteurs de Mais, Institut Technique des Céréales et des Fourages, Direction de la Météorologie Nationale, Pau, Paris, 35 pp.

Bloc, D., Gouet, J.P., Lorgeou, J., Haudecoeur, H. and Taillet, D., 1984. Besoins en températures des variétés de mais. Association Générale des Producteurs de Mais, Institut Technique des Céréales et des Fourages, Pau, Paris.

Chen, J., 1984. Uncoupled multi-layer model for the transfer of sensible and latent heat flux densities from vegetation. Boundary-Layer Meteorol., 28: 213-226.

Claassen, M.M. and Shaw, R.H., 1970a. Water deficit effects on corn. I. Vegetative components. Agron. J., 62: 649-652.

Claassen, M.M. and Shaw, R.H., 1970b. Water deficit effects on corn. II. Grain components. Agron. J., 62: $652-655$.

Commission of the European Communities, 1985. Soil map of the European Communities at scale 1:1 000000 . Directorate-General for Agriculture, CEC, Luxembourg.

Cure, J.D., 1985. Carbon dioxide doubling responses: a crop survey. In: B.R. Strain and J.D. Cure (Editors), Direct Effects of Increasing Carbon Dioxide on Vegetation. DOE/ER-0238, US Dep. of Energy, Washington, DC, pp. 99-116.

Cure, J.D. and Acock, B., 1986. Crop responses to carbon dioxide doubling: a literature survey. Agric. For. Meteorol., 38: 127-145.

Denmead, O.T. and Shaw, R.H., 1960. The effects of soil moisture stress at different stages of growth on the development and yield of corn. Agron. J., 52: 272-274.

Derieux, M. and Bonhomme, R., 1982a. Heat unit requirements for maize hybrids in Europe. Results of the European FAO sub-network. I. Sowing-silking period. Maydica, 27: 59-77.

Derieux, M. and Bonhomme, R., 1982b. Heat unit requirements for maize hybrids in Europe. Results of the European FAO sub-network. II. Period from silking to maturity. Maydica, 27: 79-96.

Easterling, W.A., McKenney, M.S., Rosenberg, N.J. and Lemon, K.M., 1992. Simulations of crop response to climate change: effects with present technology and no adjustments (the 'dumb farmer' scenario). Agric. For. Meteorol., 59: 53-73.

Easterling, W.A., Rosenberg, N.J., Lemon, K.M. and McKenney, M.S., 1992. Simulations of crop responses to climate change: effects with present technology and currently available adjustments (the 'smart farmer' scenario). Agric. For. Meteorol., 59: 75-102.

Efdé, S., 1990. Modellering van de drogestofopbrengst en de voederwaarde van snijmais. Report, Department of Theoretical Production Ecology, Wageningen Agricultural University, 58 pp. 
Frére, M. and Popov, G.F., 1979. Agrometeorological crop monitoring and forecasting. FAO Plant Prod. Prot. Pap., 17, 64 pp.

Goudriaan, J., 1977. Crop micrometeorology: a simulation study. Simulation Monographs, Pudoc, Wageningen.

Goudriaan, J., 1986. A rimple and fast numerical method for the computation of daily totals of crop photosynthesis. Agric. For. Meteorol., 38: 249-254.

Goudriaan, J. and Unsworth, M.H., 1990. Implications of increasing carbon dioxide and climate change for agricultural productivity and water resources. In: Impact of Carbon Dioxide, Trace Gases, and Climate Change on Global Agriculture. ASA Special Publication 53. American Society of Agronomy, Crop Science Society of America, and Soil Science Society of America, Madison, WI, pp. 111-130.

Goudriaan, J. and van Laar, H.H., 1978. Calculation of daily totals of the gross $\mathrm{CO}_{2}$ assimilation of leaf canopies. Neth. J. Agric. Sci., 26: 373-382.

Houghton, J.T., Jenkins, G.J. and Ephraums, J.J. (Editors), 1990. Climate Change: The IPCC Scientific Assessment. Report of Working Group I of the Intergovernmental Panel on Climate Change. Cambridge University Press, Cambridge, $365 \mathrm{pp}$.

Kenny, G.J., Harrison, P.A. and Parry, M.L., 1993. EPOCH Project: the effects of climate change on agricultural and horticultural potential in the EC. Final Project Report, Environmental Change Unit, University of Oxford-European Communities, Oxford-Brussels.

Kimball, B.A., 1986. Influence of elevated $\mathrm{CO}_{2}$ on crop yield. In: H.Z. Enoch and B.A. Kimball (Editors), Carbon Dioxide Enrichment of Greenhouse Crops. Vol. II: Physiology, Yield, and Economics, CRC Press, Boca Raton, FL, pp. 105-115.

King, D. and Daroussin, J., 1989. Test for estimating the available soil moisture reserve using the European Community soil map on the scale of 1000000 . In: H.A.J. van Lanen and A.K. Bregt (Editors), Application of Computerized EC Soil Map and Climate Data. Proceedings of Workshop, November 1988, Wageningen, EUR12039, Commission of the European Communities, Luxembourg, pp. 87-105.

Nonhebel, S., 1993. The importance of weather data in crop growth simulation models and assessment of climatic change effects. Ph.D. Thesis, Wageningen Agricultural University, 144 pp.

Reinds, G.J., de Koning, G.H.J. and Bulens, J.D., 1992. Crop production potential of rural areas within the European Communities. III: Soils, climate and administrative regions. Working Document W67, Netherlands Scientific Council for Government Policy, The Hague.

Semenov, M.A., Porter, J.R. and Delecolle, R., 1993. Simulation of the effects of climate change on growth and development of wheat in the U.K. and France. In: G.J. Kenny, P.A. Harrison and M.L. Parry (Editors), EPOCH Project: The Effects of Climate Change on Agricultural and Horticultural Potential in the EC. Final Project Report, Environmental Change Unit, University of Oxford-European Communities, Oxford-Brussels, pp. 121-136.

Shaw, R.H., 1977. Water use and requirements of maize-a review. In: Agrometeorology of the Maize Crop. WMO Publication 481, World Meteorological Organization, Geneva, pp. 119-134.

Sibma, L., 1987. Ontwikkeling en groei van mais (Zea mays L.) onder Nederlandse omstandigheden. Gewassenreeks 1, Pudoc, Wageningen.

Spitters, C.J.T., 1986. Separating the diffuse and direct component of global radiation and its implications for modeling canopy photosynthesis. Part II. Calculation of canopy photosynthesis. Agric. For. Meteorol., 38: 231-242.

Spitters, C.J.T., van Keulen, H. and van Kraalingen, D.W.G., 1989. A simple and universal crop growth simulator: SUCROS87. In: R. Rabbinge, S.A. Ward and H.H. van Laar (Editors), Simulation and Systems Management in Crop Protection. Simulation Monographs, Pudoc, Wageningen, pp. 147-181.

Te Velde, H.A., 1986. Maize for silage in the Netherlands. In: O. Dolstra and P. Miedema (Editors), Breeding of Silage Maize. Proc. 13th Congress of the Maize and Sorghum Section of EUCARPIA. Pudoc, Wageningen, pp. 3-15.

Van Diepen, C.A., van Keulen, H., Penning de Vries, F.W.T., Noy, I.G.A.M. and Goudriaan, J., 1987. Simulated variability of wheat and rice yields in current weather conditions and in future weather when ambient $\mathrm{CO}_{2}$ has doubled. Simulation Rep. CABO-TT 14, Centre for Agrobiological Research (CABO), Wageningen, 40 pp.

Van Diepen, C.A., Rappoldt, C., Wolf, J. and van Keulen, H., 1988. Crop growth simulation model 
WOFOST version 4.1, documentation. SOW-88-01, Centre for World Food Studies, Wageningen, 299 pp.

Van Diepen, C.A., Wolf, J., van Keulen, H. and Rappoldt, C., 1989. WOFOST: a simulation model of crop production. Soil Use Manage., 5: 16-24.

Van Diepen, C.A., de Koning, G.H.J., Reinds, G.J., Bulens, J.D. and van Lanen, H.A.J., 1990. Regional analysis of physical potential of crop production in the European Community. In: J. Goudriaan, H. van Keulen and H.H. van Laar (Editors), The Greenhouse Effect and Primary Productivity in European Agro-ecosystems. Pudoc, Wageningen, pp. 74-79.

Van Heemst, H.D.J., 1988. Plant data values required for simple crop growth simulation models: review and bibliography. Simulation Rep. CABO-TT 17, Centre for Agrobiological Research (CABO)Department of Theoretical Production Ecology, Wageningen Agricultural University, Wageningen, $100 \mathrm{pp}$.

Van Keulen, H. and Wolf, J. (Editors), 1986. Modelling of agricultural production: weather, soils and crops. Simulation Monographs, Pudoc, Wageningen, 479 pp.

Van Keulen, H., Berkhout, J.A.A., van Diepen, C.A., van Heemst, H.D.J., Janssen, B.H., Rappoldt, C. and Wolf, J., 1987. Quantitative land evaluation for agro-ecological characterization. In: A.H. Bunting (Editor), Agricultural Environments. Characterization, Classification and Mapping. CAB International, Wallingford, pp. 185-197.

Wolf, J., 1993. Effects of climate change on wheat production potential in the European Community. Eur. J. Agron., 2: 281-292.

Wolf, J. and van Diepen, C.A., 1991. Effects of climate change on crop production in the Rhine basin. Rep. 52, DLO, The Winand Staring Centre-Rijkswaterstaat RIZA, Wageningen-Lelystad, 144 pp. 